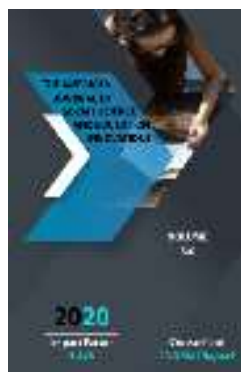

\title{
Hydrochemical Analysis Of The Aydar-Arnasay Lake System
}

Dilfuza Imamova

Associate professor, JSPI Department of Biology Teaching Methods PhD., Uzbekistan

Journal Website: http://usajournalshub.c om/index,php/tajssei

Copyright: Original content from this work may be used under the terms of the creative commons attributes 4.0 licence.

\section{ABSTRACT}

Hydrochemical analysis of water flow in the Aydar-Arnasay lake system was conducted.

\section{KEYWORDS}

Aydar-Arnasay lake system, salts and other chemical elements, collector-ditch waters, Shardara reservoir, atmospheric precipitation, wind speed, sand-salt particles.

\section{INTRODUCTION}

The inflow of salts and other chemical elements, compounds into the Aydar-Arnasay lake system is associated with collectordrainage waters, water discharged from the Shardara reservoir and groundwater, as well as atmospheric precipitation.

The amount of salts in the water discharged from the Shardara reservoir is not large. The average salinity of the Syrdarya is 0.9-1.0 g / dm3. In recent years, $1.9 \mathrm{mln}$. tons of salts [1. Alibekov L].

\section{THE MAIN PART}

The water coming through the collectorditches is the basis of the water balance of the Aydar-Arnasay lake system. According to 
various estimates, the volume of collector water is 2-3 km3. In 1993-2019, the average mineralization level of all collector-drainage waters was estimated at $4.3 \mathrm{~g} / \mathrm{dm} 3$, and the annual variability in the amount of mineralization was 2.6-6.5 g/ dm3. In this case, the total amount of salt coming through the collector-ditches during the year is $10.2 \mathrm{mln}$. tons [2. Gudalov M].

The amount of salts that fall into the lakes with atmospheric precipitation is much lower than in collector-drainage waters. We recorded the annual rainfall of $150 \mathrm{~mm}$ to $470 \mathrm{~mm}$ in the Aydar-Arnasay lakes. It is estimated that the average annual rainfall is $270 \mathrm{~mm}$ in Lake Tuzkon and $220 \mathrm{~mm}$ in the western part of Lake Aydarkol. According to E.N. Gorelkin (1979), the salts in precipitation on lakes are 6-9.5 g / $\mathrm{km} 3$. According to this calculation, 20-40 thousand tons of salt fall into the lake system annually with atmospheric precipitation.

More salts come with groundwater than with atmospheric precipitation. Groundwater in the Aydar-Arnasay lake system comes from the Nurata Mountains, the Kyzylkum Desert, the Mirzachul region, and the Shardara Reservoir. They move between layers in their path, bringing salts between rocks. The amount of salts in the groundwater coming from Mirzachol to Tuzkon and Arnasay is $\mathrm{N}$. Khodjiboev estimated it at $1.6 \mathrm{~g} / \mathrm{km} 3$. Groundwater from the Nurata Mountains is mostly fresh, and the amount of salts increases as they approach Lake Aydarkol. The amount of salts in the boreholes and well waters near the southern shores of Lake Aydarkol is 0.2-1 $\mathrm{g}$ / km3. In general, the average salinity level of groundwater coming from the surrounding areas to the Aydar-Arnasay lake system is $5.2 \mathrm{~g}$
$/ \mathrm{km} 3$, and 200,000 tons of salts come to it annually [3. Gudalov M].

\section{RESULTS AND DISCUSSIONS}

In these calculations, no salt was added to the Aydar-Arnasay lake system by wind from the surrounding areas. The Aydar-Arnasay lake system is surrounded by salt marshes, salt marshes in the summer, and a salty muddy coastal zone around the lakes. In the dry, hot months of the year, powdered mixed salts are lifted into the air by wind from these saline areas, and some of them fall into the lakes.

The results of the study showed that in desert conditions, the ruminants are rapidly eroded by the wind. In the upper crust of the brine, when particles with a diameter of $1 \mathrm{~mm}$ make up 70\% of this crust, the salt and dust particles begin to fly into the air at a wind speed of 7-8 m/ $\mathrm{s}$. The soft porous layer beneath the hard shell collapses at a wind speed of $3.7 \mathrm{~m} / \mathrm{s}$ and the particles rise into the air [4. Gudalov M].

According to many researchers, the wind speed in the deserts, which blows dust mixed salts from the surface, is $8 \mathrm{~m} / \mathrm{sec}$. As the wind speed increases from this speed, its absorption and launch activity of the decomposed material increases. Aydar-Arnasay used data from four meteorological stations (Dustlik, Mashiquud, Nurata, Yangikishlak) located around the lakes to determine the wind strength regime around the lakes. At these meteorological stations, once a month, the average daily wind speed was observed to be large (from 5.5 to $9.2 \mathrm{~m} / \mathrm{sec}$ ). At these velocities, dusty mixed salt particles are blown more into the air. According to the same daily indicators, the amount of dust and salt was calculated per month. This figure was 
multiplied by 12 to determine the annual amount.

In determining the size of sand-salt particles released into the air by wind from the AydarArnasay lake system, O. E. Semenov (1970) method was used. O. E. Semenov measured the movement of sand-salt mixtures due to wind using a special experiment in South Kazakhstan. In this case, the diameter of the sand particles was taken to be 130 microns, the sand-mixed clay soil particle to be 88 microns, and the salt particle to be 40 microns. In 1987, the Aydarkol water level was low and the length of the water-free shoreline was $100 \mathrm{~km}$. At this time, it was found that the largest amount of salt with a diameter of 40 microns was released by the wind in the amount of annual dust emissions. Their amount is 2.28 million depending on wind speed. 6.74 million tons tons. At that time, the amount of sand with a diameter of 130 microns was 10 to 100 times less than the salts and amounted to 10.4 to 187 thousand tons [5. Gudalov M].

In 1987, due to the lowest water level in the Aydar-Arnasay lake system, a large area on the eastern shores of Lake Tuzkan was also free of water, and saline soils and salt-covered pits became widespread. How much salt and dust was removed in this area due to the wind is calculated by N. G Vershchagina, A. A.Shchetinnikov, A.M.Mukhamatzyanova (2010). Calculations were performed for the $0.05 \mathrm{~m}$ top layer of soil. According to these authors, when the wind speed is $8-9 \mathrm{~m} / \mathrm{sec}$, up to 45 tons of dust and salts are emitted from one hectare of saline soils, up to 4.9 tons from sandy soils, and up to 1.5 tons from sandy soils. Of these volatile salts, $30 \%$ are sulfates and $25 \%$ are chlorides. During winds of the same strength, up to 1.2 tons of chlorides are emitted from each hectare of swamps and spread to neighboring areas.

These researchers have also studied the transport of salts from the periphery of Lake Tuzkon to remote areas. According to their calculations, 40 microns of salt particles from the shores of Lake Tuzkon were carried by air currents at a distance of $26 \mathrm{~km}$, and the dustsalt mixture from the atmosphere fell from 52 $\mathrm{kg}$ per $1 \mathrm{~km} 2$. Given that the winds in the AydarArnasay lake system are more northnorthwesterly throughout the year, most of the salts released into the atmosphere by the wind around the lake fall on the irrigated lands of Jizzakh region.

Most of the irrigated land in the western part of Jizzakh region is saline. Here, the amount of salts in the 1.0-meter-thick soil layer is $270-460$ t / ha (Kamilov, 1978). These saline soils are salted by air from the Aydar-Arnasay lake system throughout the year, further increasing soil salinity. According to. N. G Verashchagina, A. A Shchetinnikova, A.M. Mukhametzyanova (2010), about $1 \%$ of the salt rising from the lake area falls on irrigated lands $25 \mathrm{~km}$ from the lakes, which is 63.4 thousand tons per year. However, the researchers note that with atmospheric precipitation and dust coming through the upper atmosphere, 0.28 tons of dust and salts fall per hectare per year in these areas.

Currently, $70-80 \%$ of irrigated lands in Jizzakh and Syrdarya regions are saline to varying degrees. Under these conditions of salinity, the contribution of salts coming through the air is also large. Sulfates and chlorides coming from neighboring areas through the air do the most damage to crops. It is becoming clear that the level of the Aydar-Arnasay lake system will decrease in the future. In this case, the area of 
saline soils around the lake, which has been emptied of water, expands, resulting in increased movement through the wind. This causes dust mixed salts to spread to areas within a radius of several tens of kilometers around the lake. Strong continuous winds carry the salts to the slopes of Nurata Mountain, as well as to the eastern regions of Mirzachul. It has been reported in the scientific literature that salt-mixed dust particles rise to several hundred meters, even several kilometers, and are carried away by currents for hundreds of kilometers during strong dust storms [6. Sharipov Sh].

The study of the movement of salts by wind is of great scientific and practical importance. The data we have presented above are not based on specific field-based experimental studies. These studies are based on research conducted in South Kazakhstan. For this reason, the accuracy of the figures given is not great. But the issue here is not whether the numbers are right or wrong, the issue is the study of the movement of salts through the air, the problem of their movement in our desert conditions. This problem has hardly been studied by us using the field experimental method. The Aydar-Arnasay lake system, ephemeral lakes that dry up in the summer around the Bukhara oasis, salt marshes around the Khorezm oasis, salt marshes in the Lower Amudarya, from which salt migration due to wind should be studied through permanent monitoring posts. We do not even have an estimate of the amount and composition of salts coming to Mirzachul, Bukhara oasis, Lower Amudarya oasis. This hinders the development of measures to improve the reclamation of lands, the ecological conditions of oases, the issuance of scientific conclusions, proposals and recommendations [7. Sharipov $\mathrm{Sh}$.

\section{CONCLUSION}

Based on the landscape-ecological research conducted in the territory of Aydar-Arnasay lake system, taking into account the ecological situation in the region and studying the effect of salt-dust mixed salts coming through the air streams, it is necessary to carry out the following monitoring to quantify salt-dust in the air:

- Installation of special devices for trapping dust salts at meteorological stations around the Aydar-Arnasay lake system and quantitative assessment of the results obtained;

- Qualitative and quantitative assessment of salt and other chemical elements on the basis of laboratory analysis;

- Determination of the distribution of dust and salts in the Aydar-Arnasay lake system;

- Installation of dust and sand traps in the eastern part of Aydarkol, Tuzkon and Arnasay lakes, as well as in the northern part of Aydarkol and Tuzkon lakes, taking into account that the annual wind direction in the territory of the Aydar-Arnasay lake system is mainly from the north and northwest.

\section{REFERENCES}

1. Alibekov L, Alibekova S, Hazarov I, Gudalov $M$. About some regularities of degradation geosystems in Central Asia. Tatranka Javorina, Slovakia, 2012, Vol 21, № -1, 42-44 $r$

2. Gudalov M. Foundation of Aydar-Arnasay lakes system and their effects on the environmental landscape. Nature and 
Science.Volume 17, Number 11 November 25, 2019 USA New York.

3. Gudalov M., Zikirov B. Metnods of studying the landscapes around the Aydar-Arnasay lake system. International engineering journal for research \& development. Vol - 5 , Issue - 7, 2020 India.

4. Gudalov M., Zikirov B., Imamova D. Predicting changes in landscares around the Aydar-Arnasay lake system. Accerted in the journal The American of Engineering and Technology. Volume - 02, Issue - 10, October 2020.

5. Gudalov M., Gozieva M. Ways to develor modern ecoturism in the Zamin basin. International engineering journal for research \& development. Vol - 5, Issue - 7, 2020 India.

6. Sharipov Sh, Gudalov M, Shomurodova Sh. Geolologic situation in the Aydar-Arnasay colony and its atropny. Journal of Critical Reviews. Volume 7, Issue 3, 2020 Malaysia Kuala Lumpur.

7. Sharipov Sh, Shomurodova Sh, Gudalov M. The use of the mountain kars in the tourism sphere in cort and recreation zone of Chimgan-Charvak. Journal of Critical Reviews. Volume 7, Issue 3, 2020 Malaysia Kuala Lumpur.

8. Mirkomil, G., Gulshoda, J., \& Ilyos, J. (2020). Ways To Develop Ecotourism In The Molguzar Mountains. The American Journal of Applied sciences, 2(11), 1-5

9. Gudalov, M., \& Imamova, D. (2020). Development of Ecoturism In AydarArnasay Lakes System And Its Surroundings. The American Journal of Applied sciences, 2(10), 150-153.

10. Omonov, Q., \& Karimov, N. (2020). Importance Of Ancestoral Heritage. The
American Journal of Social Science and Education Innovations, 2(09), 196-202.

11. Karimov, N. R. (2020). A True Successor of Great Central Asian Scholars. Journal «Bulletin Social-Economic and Humanitarian Research,(7), 62-69.

12. Turakhanovna, S. U. (2020). The Issue of Literary Heroism in Korean Literature. Solid State Technology, 63(6), 1779-1785.

13. Kariev, A., \& Aminov, H. (2020). New information about Imam al-Zarnūjī and his work “Ta'lim al-Muta'allim”. Solid State Technology, 63(6), 2372-2387. 